УДК 35:005.7-045.38](477)

DOI: 10.34132/pard2021.11.01

\title{
ВІДДАЛЕНА РОБОТА ЯК НОВА МОДЕЛЬ ОРГАНІЗАЦЙНО-ІНСТИТУЦІЙНОГО РОЗВИТКУ ДЕРЖАВНОЇ СЛУЖБИ УКРАЇНИ
}

Алюшина Н. О., голова, Національне агентство України 3 питань державної служби, канд. психол., наук, доцент, м. Київ, Україна.

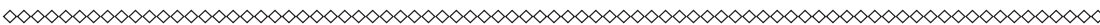

Розкрито результати дослідження практики організації віддаленої роботи на державній службі України під час карантину, спричиненого COVID-19. Здійснено опис способів та особливостей організації віддаленої роботи. Висвітлено відмінності щзодо способів організаиії віддаленої роботи у державних органах різних рівнів юрисдикції. Досліджено оиінку державними службовиями рівня своєї ефективності, якості та виконавської дисципліни з часу переходу на віддалену роботу. Здійснено порівняння ставлень до особливостей віддаленої роботи за категорією посади, віком, стажем та статтю. Визначено проблеми, які потребують вирімення в рамках запровадження віддаленого режиму роботи. Окреслено п'ять основних трендів організації віддаленої роботи: стимулювання навчання та саморозвитку; популяризація IT-інструментів на державній службі; усвідомлення важливості комунікації та взаємодї; розвиток інструментів нематеріального стимулювання команди; адаптивність праичвників до нових умов роботи, помірний опір змінам.

Ключові слова: віддалена робота, державна служба, державні службовиі, організачія віддаленої роботи, COVID-19, управління персоналом.

Постановка проблеми у загальному вигляді. Відповідно до статті 29 Закону України «Про захист населення від інфекційних хвороб» 3 метою запобігання поширенню на території України го- 
строї респіраторної хвороби COVID-19, спричиненої коронавірусом SARS-CoV-2 (далі - COVID-19), з урахуванням рішення Державної комісії з питань техногенно-екологічної безпеки та надзвичайних ситуацій від 10 березня 2020 року Кабінет Міністрів України11 березня Кабінет Міністрів України установив з 12 березня 2020 року на всій території України карантин.

3 огляду на це, виникла необхідність збереження сталості та якості функціонування державних органів. Для запровадження практики віддаленої роботи було внесено зміни до Типових правил внутрішнього службового розпорядку (наказ Національного агентства України з питань державної служби від 13 березня 2020 року № 39-20, зареєстрований в Міністерстві юстиції України 16 березня 2020 року за № 277/34560). Відтак, державні службовці отримали можливість виконувати завдання за посадою за межами адміністративної будівлі державного органу.

Аналіз останніх досліджень і публікацій. У зв'язку із коронавірусом COVID-19 значна кількість державних службовців перейшла на віддалений або комбінований режим роботи. Практика віддаленої роботи на державній службі, хоч і не була масовою, але існувала в інших країнах до впровадження карантину, наприклад у Великобританції, Польщі, Ірландії. В умовах карантину, задля збереження сталості та якості функціонування державних органів, виникла необхідність масового та несподіваного переведення державних службовців на віддалену роботу. Під час пандемії більшість країн переглянули або розробили нормативно-правове регулювання віддаленої роботи на державній службі, інші методологічні та інструктивні матеріали.

Для України можливість віддаленої роботи на державній службі стала однією з інновацій. Для запровадження практики віддаленої роботи було внесено зміни до Типових правил внутрішнього службового розпорядку (наказ Національного агентства України 3 питань державної служби від 13 березня 2020 року № 39-20, зареєстрований в Міністерстві юстиції України 16 березня 2020 року за № 277/34560) [1]. Відтак, державні службовці отримали можливість виконувати завдання за посадою за межами адміністративної будівлі державного органу. 
Перехід на віддалену роботи посприяв суттєвим змінам в організації роботи, змусив змінити звичні засоби спілкування, переглянути підходи до керівництва та управління ефективністю. Відповідно трансформувалася культура комунікації та взаємодії на державній службі. Багатьом працівникам довелося в короткі терміни освоїти нові професійні знання, утримати або сформувати сприятливий соціально-психологічний клімат в колективах. Розпочався масовий процес адаптації до нових умов роботи.

Особливості організації віддаленої роботи, взаємодії та професійного розвитку, зокрема під час пандемії, відображено у наукових працях таких дослідників: С. Ахуджа, О. Бондаренко, Л. Васюренко, П. Каур, В. Кривошеєва, Т. Мірза, С. Муталіб, С. Невмержицька, К. Павлова, С. Панда, О. Петяк, С. Рудакова, А. Руденок, Т. Тардаскіна, М. Хасан, Н. Ханецька, М. Хусейн, С. Шафіє, Л. Щетініна та інші.

Формулювання цілей статті (постановка завдання) - проаналізувати практику організації віддаленої роботи у державних органах та визначити основні аспекти, що впливають на процес організації віддаленої роботи, позитивні та негативні впливи на державних службовців та державний орган, а також готовність системи державного управління до впровадження нових умов роботи для забезпечення сталої, безперебійної роботи державних органів в умовах карантину.

Основним завданням цього дослідження є збір інформації щодо стану впровадження режиму віддаленої роботи в державних органах та надання первинних інсайтів заінтересованим сторонам керівникам державних органів, структурних підрозділів, їх працівникам, службам управління персоналом, державним органам та іншим сторонам.

Отримані за результатами дослідження висновки та рекомендації пропонується використовувати при підготовці необхідних заходів щодо організації роботи у віддаленому режимі та подальших дослідженнях.

Виклад основного матеріалу дослідження. У рамках дослідження опрацьовано відповіді на відкрите запитання: «3 якими труд- 
нощами Ви стикаєтеся працюючи віддалено?». Аналіз генеральної сукупності відповідей і тверджень респондентів на відкрите запитання дозволив виділити вибіркову сукупність відповідей, які згруповано за 8 напрямами (рис. 1). Представимо основні положення за цими напрямками.

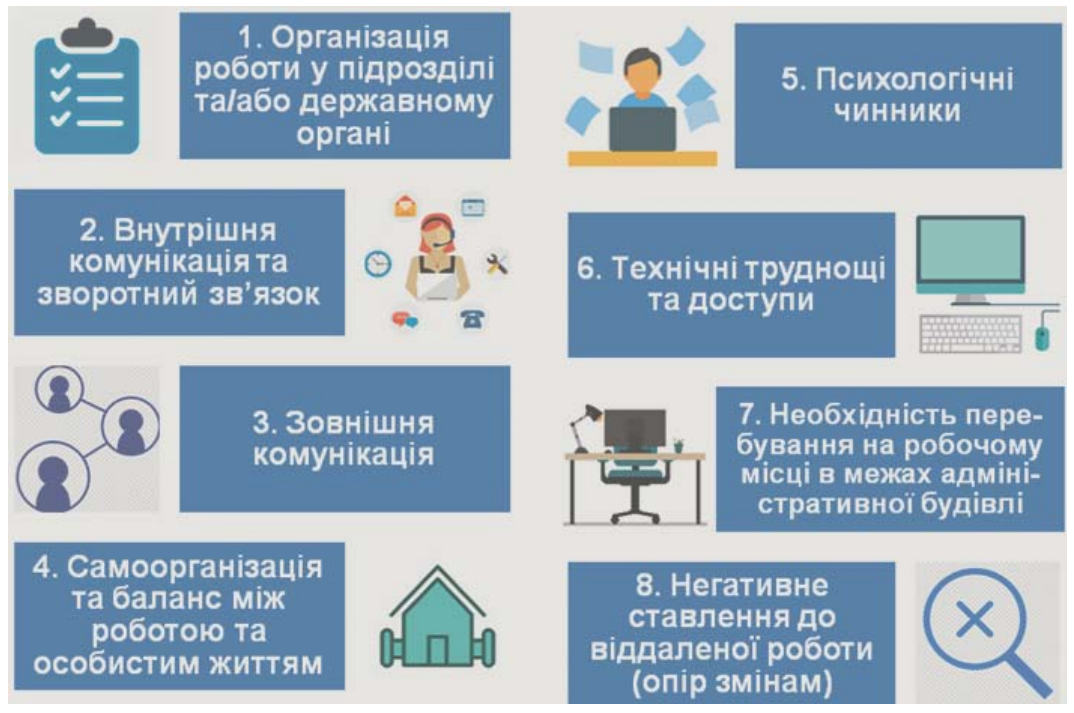

Puc.1. Проблеми, з якими стикаються державні службовців в умовах віддаленої роботи.

1. Організація роботи у структурному підрозділі та/або державному органі. На думку респондентів, які надали відповідь на відкрите запитання, у більшості випадків рівень організації віддаленої роботи у структурному підрозділі та/або державному органі недостатній чи низький з огляду на наступні чинники.

\section{1. Організаційний.}

Державними службовцями зазначено про формальний підхід до організації віддаленої роботи, що обумовлено відсутністю загальної нормативно-правової бази та локальних нормативних рішень державного органу щодо дистанційної роботи. Ухвалені рішення не достатні чи виконуються не в повному обсязі. Також зазначено про 
відсутність планування, контролю, методичної допомоги зі сторони центральних органів виконавчої влади щодо підпорядкованих установ та організацій.

Недостатньо відпрацьовано або не запроваджено механізми оперативного підписання документів у керівництва та співвиконавців. Наприклад, система електронного документообігу потребує паперового підтвердження. Присутня практика, коли керівник не підписує електронний документ поки не буде паперовий екземпляр із візами. Витрачається тривалий час на візування i погодження наказів, у зв'язку з обмеженням здійснювати контроль $\mathrm{i}$ нагляд у рамках повноважень державного органу.

Виявлено, що окремі структурні підрозділи (наприклад, юридичні служби) відмовляються опрацьовувати та правити внутрішні документи, підготовлені іншими структурними підрозділами, в електронному вигляді. Через це працівники, що працюють віддалено, змушені їздити на роботу, тобто не дотримуватися режиму віддаленої роботи. Відсутній алгоритм погодження рішень у разі відсутності керівників інших структурних підрозділів.

Через неналежний рівень організації віддаленої роботи частина опитуваних зазначили, що припинили виконувати свої посадові обов'язки і робота не здійснюється.

2. Управлінський.

В цілому, більшість респондентів відповіли, що у керівників вищого та середнього рівнів відсутні або недостатній рівень знань, умінь і навичок для організації віддаленої роботи. Наявне нерозуміння важливості вироблення нових підходів щодо планування, моніторингу, контролю та методичної підтримки працівників та роботи структурних підрозділів.

Розподіл посадових обов'язків і робоче навантаження (обсяг роботи) на працівників, що працюють дистанційно, здійснюється нерівномірно без дотримання пропорційності та врахування їх професійних компетентностей, покладання надмірної відповідальності та невластивого функціоналу на працівників. Наявні випадки відсутності планування та розподілу обов'язків між працівниками 
структурних підрозділів державних органів. В окремих випадках керівництво не делегує виконання посадових обов'язків спеціалістам, або доручаються завдання, що не входять до функціональних обов'язків, та не стосуються роботи структурного підрозділу.

Дослідження дозволяє припустити наявність внутрішнього конфлікту між керівництвом та підпорядкованими працівниками через відсутність довіри, нерозуміння дій та мотивів один одного.

3 боку керівників наголошено на неможливості контролювати ефективність та якість виконання підлеглими поставлених завдань.

Водночас з боку підпорядкованих працівників зазначено про нерозуміння моделі дистанційної роботи, невміння менеджменту керувати працівниками віддалено. На їх думку, це призводить до виникнення стресових ситуацій, незважаючи на те, що робота виконана вчасно і якісно.

Також наявні випадки запровадження надмірної кількості звітів щодо виконаної віддаленої роботи у зв'язку з цим можна зробити припущення про відсутність дієвої системи моніторингу та контролю виконання завдань.

На думку респондентів, наявні труднощі в організації роботи та контролю за виконанням завдань призводять до погіршення якості та виконавської дисципліни.

\section{3. Цифрової грамотності.}

У значній кількості відповідей наголошено на недостатньому рівні цифрової грамотності колег і співробітників, володіння ними сучасними методами комунікації або обміну інформацією 3 використанням IT рішень.

\section{4. Комунікативний.}

Респондентами відзначено відсутність роз'яснення та методичної підтримки з боку керівництва щодо віддаленої роботи. Несвоєчасне забезпечення підпорядкованих працівників необхідною для роботи інформацією. Відсутність інформації у працівників щодо того, хто чим займається.

Також зазначено, що не налагоджена оперативна взаємодія у межах підрозділу, 3 керівництвом, 3 працівниками інших структурних підрозділів. 
Окремої уваги заслуговує твердження щодо небажання та невміння відділу управління персоналом працювати із застосуванням засобів сучасних технологій та співпрацювати з колегами з інших відділів.

Загалом комунікація віддаленої роботи серед працівників і між структурними підрозділами недооцінена та негативно впливає на перебіг роботи та якість результатів.

\section{5. Понаднормова робота.}

Більшість відповідей респондентів містить твердження про ненормований робочий день через відсутність чіткої організації робочого часу. Відсутність чи недостатнє планування призводить до того, що обсяги виконання робіт структурного підрозділу перевищують 8 годин робочого часу. Наявні випадки, коли безпосередній керівник ставить завдання після закінчення робочого часу, у вихідні чи святкові дні.

\section{6. Демотивачія.}

Виявлено випадки низького рівня мотивації працівників, який, зокрема, пов'язаний 3 практикою зменшення заробітної плати тим, хто працює у дистанційному режимі. При цьому зазначено на збільшенні обсягу завдань, що виконуються дистанційно. Відмічено, що деякі працівники вважають, що у них відпустка.

2. Внутрішня комунікація та зворотний зв'язок. Більшістю респондентів, якими надано відповідь на відкрите запитання, наголошено на дефіциті комунікації з керівництвом та колегами, нестачі зворотного зв' язку від вищого керівництва. Також відмічено низьку оцінку стану міжособистісних відносин та командного духу в колективах.

Виникають труднощі у встановленні оперативного зв’язку 3 працівниками інших структурних підрозділів, а координація з деякими структурними підрозділами відбувається через посередників.

Частина респондентів зазначили про відсутність можливості обговорити, висловити та почути позицію колег щодо напрацьованих документів.

Також наголошено на тому, що важко проводити обговорення великих стратегічних документів, виконавцями яких $є$ кілька структурних підрозділів. 
За результатами аналізу виявлено недостатній рівень комунікації, співпраці та зворотного зв’язку в державних органах, їх структурних підрозділах.

3. Зовнішня комунікація. Чимало респондентів відзначали, що мають складнощі у встановленні оперативного зв'язку 3 працівниками інших державних органів i стейкхолдерами. Витрачається багато зусиль та робочого часу на пошук необхідного працівника, зокрема, через відсутність актуальних списків номерів телефонів та електронної пошти працівників. Також зазначено, що не всі колеги налаштували робочу електронну пошту вдома.

Виникають труднощі в отриманні своєчасної інформації від працівників інших державних органів для оперативного виконання поставлених завдань.

Крім того, респондентами наголошено, що не можливо зв'язатися з виконавцями листів, оскільки вони вказують робочий номер телефону для зв'язку, хоча самі працюють за межами адміністративної будівлі.

\section{4. Самоорганізація та баланс міжс роботою та особистим} жситтям.

Серед труднощів, з якими стикаються респонденти, працюючи віддалено, встановлено дисбаланс робочого часу та часу відпочинку, а також самоорганізація в роботі.

Для прикладу відібрано найбільш репрезентативні відповіді на відкрите питання, що були надані респондентами: «Важко зосередитися на одній справі», «Труднощі 3 облаштуванням робочого місця вдома», «Відсутність вдома всіх необхідних робочих матеріалів», «Труднощі зі складанням покрокових списків щоденної роботи», «Складно віднайти баланс між робочим часом та часом відпочинку», «Зникають рамки між робочим часом та особистим життям», «Робота стає безперервною», «Якщо раніше ми з колегами після 22:00 листувалися тільки в екстрених випадках, то зараз такі повідомлення стають нормою, що спричиняє дискомфорт», «Робота з 8:00 до 23:00».

Значна частина респондентів зазначила, що їм складно поєднувати виконання віддаленої роботи та одночасного 
дистанційного навчання дитини, виконання щоденних буденних справ, працювати, коли вдома дитина дошкільного віку та вся сім'я.

Можна зробити логічне припущення, що віддалена робота без належної підготовки (зокрема, навчання, методичного супроводу) та підтримки з боку керівництва, колег і сім'ї негативно впливає на продуктивність працівників через втрату відчуття «реального» часу.

5. Психологічні чинники. Більшість респондентів, які надали відповідь на відкрите питання, наголосили на наступних тривожних проявах:

$\checkmark \quad$ відчуття соціальної та інформаційної ізоляції;

$\checkmark$ відсутність мотивації;

$\checkmark$ складність концентруватися на поставлених завданнях, відволікання;

$\checkmark \quad$ стрес та напруга через безперервну роботу та неможливість чітко організувати свій робочий день та особистий час;

$\checkmark \quad$ переживання та сум щодо відсутності очного спілкування 3 колегами, дискомфорт у комунікації через відсутність можливості спостерігати за невербальною поведінкою;

$\checkmark \quad$ втрата деяких каналів сприйняття та передачі інформації, часткова втрата емпатії.

Результати аналізу відповідей підтверджують важливість очного спілкування. Водночас аналіз інших пунктів цього розділу дозволяє стверджувати, що завчасна належна підготовка (самостійне чи спільне 3 колегами опанування принципів, інструментів і методів віддаленої роботи) та підтримка «здорової» онлайн-комунікації дозволяє попередити виникнення чи подолати негативні наслідки та психоемоційні стани під час роботи на відстані та у період самоізоляції.

6. Технічні труднощі та доступи. Більшість респондентів висловити твердження та навели приклади наявних технічних труднощів, відсутності налаштувань, доступів і збоїв у роботі на відстані.

Неодноразово зазначалося про відсутність налагодженої системи електронного документообігу та збоїв в його роботі. Серед 
респондентів переважає твердження про непоодинокі випадки, коли відповідними структурними підрозділами не проведено налаштування віддалених робочих місць працівників, не забезпечено комп'ютерною технікою та доступами, наприклад, до робочої електронної пошти, спеціалізованого програмного забезпечення.

Зокрема, твердження респондентів стосуються відсутності електронного документообігу у багатьох державних органах. У деяких державних органах, в яких налагоджено електронний документообіг, продовжується використання великого обсягу паперових документів (наприклад, попереднє візування у паперовому вигляді тощо).

Крім того наголошено на труднощах із погодженням нормативно-правових актів (пояснювальні записки, аркуші погодження, порівняльні таблиці) за допомогою системи електронного документообігу. Проблема полягає у недосконалості системи електронного документообігу (наприклад, підпис керівника державного органу має стояти на всіх документах, а система дозволяє підписувати тільки один основний документ, без додатків, де $є$ порівняльна таблиця і т. ін.).

Виявлено, що працівникам, робота яких пов’язана 3 наданням адміністративних послуг, надходять постійні скарги від громадян, які не можуть отримувати оригінали документів, у зв'язку із відсутністю можливості фізично передати їх до ЦНАП.

Окремими респондентами відзначено невміння більшості працівників користуватися сучасними засобами роботи 3 електронними документами та відсутність у колег навичок онлайнспілкування.

Як приклад, наводиться цитата респондента: «Я керівник середньої ланки, мені важко організовувати роботу і контролювати виконання завдань, оскільки мої підлеглі не завжди володіють потрібними навичками онлайн-спілкування, виконання більшості завдань беру на себе». Також наголошено на потребі у налаштуванні віддаленого доступу до баз даних та інформації, які є на робочому комп'ютері або локальній мережі, повільному та нестійкому Інтернет з'єднанні. 
Загалом аналіз отриманих відповідей респондентів дозволяє зробити припущення щодо відсутності єдиних підходів, стандартів i механізмів забезпечення працівників, які працюють віддалено, необхідним комп'ютерним обладнанням і програмним забезпеченням.

7. Необхідність перебування на робочому місці в межах адміністративної будівлі. Аналіз відповідей респондентів на відкрите питання виявив обставини, за умови настання яких працівники, які працюють на відстані, зазнають труднощів оскільки потребують фізичного доступу до інших працівників, приміщень, документів, інформації (даних), які знаходяться в межах адміністративної будівлі державного органу.

Наприклад, необхідність доступу до документів, які зберігаються в архіві державного органу, документів із обмеженим доступом, інших документів, які потрібні в поточній роботі, базами даних та персональних даних, матеріально-технічної бази. Також це стосується можливості використання програмного забезпечення, яке доступно (встановлено) тільки на робочому комп'ютері.

Крім того, наявні види документів, які готуються виключно в паперовому вигляді. Наприклад, листування 3 деякими органами, громадянами у паперовому вигляді, оскільки в окремих випадках для надання відповіді необхідно проставляти не електронний, а фізичний підпис. Зазначена вимога передбачена законодавством.

\section{8. Негативне ставлення до віддаленої роботи (опір змінам).} Загалом в опозиції до впровадження віддаленої роботи виявлено незначну кількість респондентів. Зазначена опозиція розглядається як очікуваний і прогнозований опір змінам через труднощі, які створюють необхідність виходити працівникам із зони комфорту. Респондентами наголошено на окремих випадках неготовності вищого керівництва державного органу, керівництва середньої ланки та працівників до віддаленої роботи.

Серед варіантів відповідей слід виділити такі цитати респондентів: «керівник органу не погодив віддалену роботу», «керівництво не дозволяє працювати віддалено та відноситься до цього скептично, хоча посадові обов'язки можна виконувати дистанційно», «працівників у колективі, що працюють віддалено 
вважають зрадниками», «присутнє нерозуміння керівництвом нових технологічних можливостей віддаленої роботи», «ніхто не хоче користуватися новітніми технологіями комунікації», «небажання та невміння адміністрації та деяких колег, що працюють в установі, працювати у дистанційному режимі».

Окремої уваги потребує таке твердження респондента: «можливість працювати дистанційно приходиться випрошувати i сприймається як величезна послуга, за яку ще прийдеться віддячити». Поряд із цим, як зазначено у відповідях респондентів, в державних органах наявна практика зменшення заробітної плати тим, хто працює віддалено. Крім того, негативно впливає на сприйняття віддаленої роботи відсутність дій з боку державного органу щодо організації переведення (логістика) працівників до місця роботи в межах адміністративної будівлі державного органу.

На основі проведеного аналізу, не можна провести чіткої межі між керівниками та підпорядкованими працівниками, водночас можна зробити припущення, що не всі працівники державного органу перебувають в опозиції до запровадження віддаленої роботи на період дії карантину та в перспективі на постійній основі як окремого виду проходження державної служби.

За результатами проведеного аналізу можна говорити про певні перспективи віддаленої роботи. Так, більшість опитаних державних службовців $(68,1 \%$ ) надалі хотіли б поєднувати віддалену роботу 3 очною, 19,6 \% - не хотіли б працювати віддалено та 12,3 \% - хотіли б перейти на віддалений режим роботи (рис. 2).

У контексті проведеного дослідження проводився аналіз намірів державних службовців продовжувати працювати віддалено. Так, хотіли б і надалі працювати віддалено серед працівників, які працюють зараз віддалено 86,5 \% та тих, що працюють віддалено та час від часу відвідують робоче місце відповідно до графіку чергувань 92,8 \%. Серед тих, хто працює у штатному режимі таких показник є дещо нижчим, хоча також вагомим та становить 66,4%.

Встановлено кореляційні зв'язки $(\mathrm{p} \leq 0,01)$ між тим як оцінює респондент ефективність, якість та виконавську дисципліну структурного підрозділу чи державного органу та його бажанням 
в подальшому працювати віддалено: чим вище державні службовці оцінюють ефективність, якість та виконавську дисципліну, тим більше вони хочуть в майбутньому працювати віддалено.

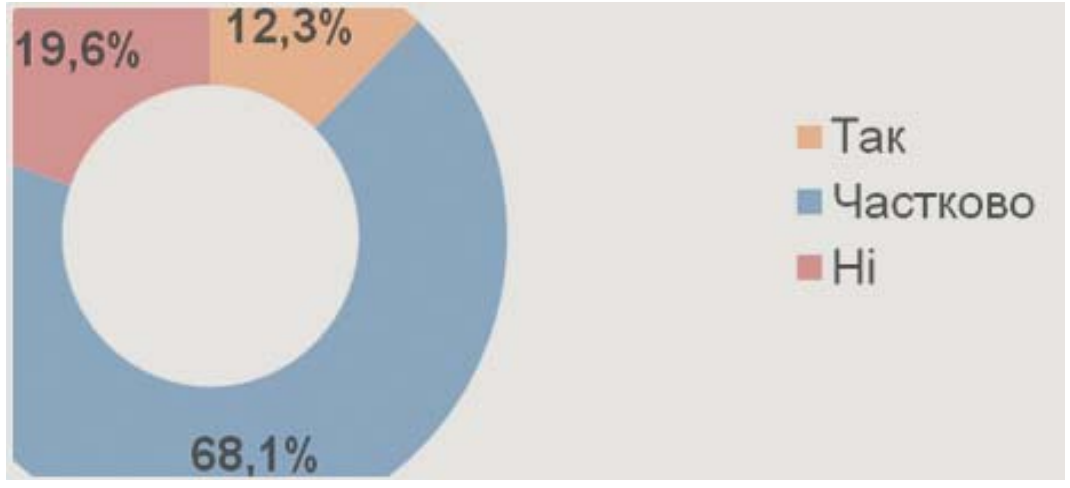

Puc. 2. Чи хотіли б Ви у майбутньому продовжувати працювати віддалено?

3'ясовано, що чим більше способів організації віддаленої роботи застосовується при роботі віддалено, тим більше державні службовці і надалі хотіли б продовжувати працювати віддалено $(\mathrm{p} \leq 0,01)$. Також визначено $(\mathrm{p} \leq 0,01)$, що державні службовці прагнуть більше працювати віддалено за умови застосування таких засобів телекомунікаційного зв'язку: Telegram, WhatsApp, Slack, Trello, Skype, Zoom, Meet, Google Docs, система електронного документообігу та телефон.

Респонденти зазначили, що якщо б рішення залежало від них, то 65,7 \% дозволили 6 працівникам свого структурного підрозділу перейти на частково віддалену роботу (поєднувати віддалену роботу 3 очною), 20,8 \% - дозволили б повністю перейти на віддалений режим роботи та 13,5 \% - не дозволили б (рис. 3 ).

Встановлено лінійну тенденцію між віком працівника та його рішенням щодо ймовірності роботи підпорядкованих працівників у віддаленому режимі. 3'ясовано, що чим старший працівник, тим більша ймовірність, що вони б не дозволили працівникам їхнього структурного підрозділу перейти на віддалену роботу $(\mathrm{H=6,907).}$ 


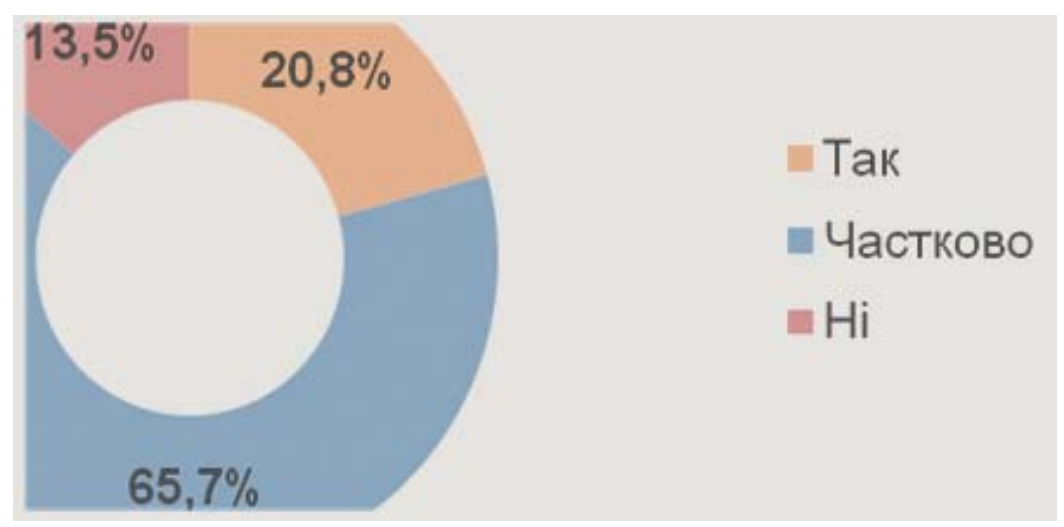

Puc. 3. Якби рішення залежало від Вас, то чи дозволили б Ви працівникам свого структурного підрозділу перейти на роботу дистанційно?

3 отриманих результатів можна констатувати, що більшість державних службовців, якщо б рішення залежало від них, дозволили б працівникам свого структурного підрозділу працювати віддалено (повністю або частково), зокрема: 95,7 \% - працівників, що працюють віддалено, а робоче місце відвідують відповідно до графіку чергувань; 90,2 \% - працівників, що працюють віддалено; 76,8 \% - працівників, що працюють в штатному режимі; 75,7 \% працівників, що не працюють (перебувають на лікарняному / довготривалій відпустці).

Резюмуючи усе вищевикладене, можемо констатувати такі результати проведеного дослідження:

1. В умовах карантину більшість державних службовців почали працювати віддалено (60,3%, 3 яких 31,3 \% - перейшли на виключно віддалений режим та 29 \% - працюють 3 дому, а робоче місце відвідують відповідно до графіку чергувань).

Чим вищий рівень державного органу, тим більша кількість державних службовців працюють віддалено. Наприклад, якщо віддалено в державних органах першого рівня в умовах карантину працює 81,8 \% державних службовців, то у державних органах 
п’ятого рівня всього 41,8 \%, що є вдвоє менше. Скоріше за все це пов'язано 3 технічними можливостями та більшою гнучкістю можливостей у прийнятті рішень в державних органах вищого рівня.

2. Найбільш поширеними способами організації віддаленої роботи визначено обмін електронними документами між працівниками $(79,1$ \%), індивідуальне телефонне спілкування $(63,5 \%)$, обмін повідомленнями шляхом застосування засобів телекомунікаційного зв'язку (62,6 \%) та листування (надсилання службової кореспонденції) шляхом застосування засобів телекомунікаційного зв'язку (60,3%).

Крім того в державних органах вищих рівнів поширеними $\epsilon$ спільна робота над документами, здійснення планування та контролю завдань структурного підрозділу онлайн, здійснення постановки щоденних завдань структурного підрозділу онлайн. Тоді як серед працівників державних органів нижчого рівня щодо використання таких способів роботи зазначило менше ніж 26 \%.

3. Найпоширенішою формою роз'яснювальної роботи в державних органах щодо організації роботи у віддаленому режимі $\epsilon$ надання усних роз'яснень (58,3\%).

4. Серед засобів телекомунікаційного зв'язку для комунікації всередині структурного підрозділу більша половина державних службовців застосовує телефон (77,6 \%), Viber (70,2 \%), електронну пошту: робочу $(66,9 \%)$ та особисту $(51,3 \%)$.

Для комунікації з працівниками інших структурних підрозділів державного органу державні службовці переважно застосовують такі засоби телекомунікаційного зв'язку, як телефон $(73,7$ \%), електронну робочу пошту (72,8 \%) та Viber (54,9\%).

Чоловіки більше, ніж жінки схильні застосовувати для комунікації в межах структурного підрозділу Telegram, Cisco Webex та Google Docs. B межах комунікації з працівниками інших структурних підрозділів державного органу чоловіки більше схильні застосовувати Telegram, WhatsApp та Cisco Webex, а жінки більше Viber та Facebook.

Працівники категорії «Б» схильні більше застосовувати різноманітні сучасні засоби телекомунікаційного зв’язку, ніж 
працівники категорії «В» (зокрема, такі як Viber, WhatsApp, Telegram, Zoom, Cisco Webex).

Працівники старшого віку надають перевагу Viber, а молодшого більше схильні застосовувати Telegram, WhatsApp, Slack, Trello, Zoom, Meet ta Google Docs.

5. За результатами порівняння застосування засобів телекомунікаційного зв'язку між працівниками що працюють у штатному режимі та віддалено не встановлено суттєвих відмінностей. При роботі віддалено суттєво зростає відсоток застосування особистої електронної пошти, системи електронного документообігу та Viber. Водночас відсоток застосування засобів дистанційної організації роботи (Trello, Slack), організації онлайн-нарад (Skype, Zoom, Meet, Cisco Webex) залишаються критично низькими та свідчать про недостатньо налагоджену роботу структурних підрозділів державних органів в умовах карантину.

6. На всіх рівнях державних органів для взаємодії у межах структурного підрозділу більшість працівників застосовує телефон, робочу електронну пошту та особисту (окрім п'ятого рівня). У представників першого рівня найбільшим попитом серед месенджерів користується Telegram, а у представників інших рівнів державних органів Viber. Система електронного документообігу частіше застосовується на першому - третьому рівнях. Це може бути пов'язано з відсутністю такої системи у більшості державних органів четвертого та п'ятого рівнів.

7.Більшість державних службовців перебувають у постійному контакті 3 колегами $(77,6$ \%) та отримують зворотний зв'язок щодо виконаної роботи $(61,6 \%)$. Водночас частина респондентів відчувають деяку ізоляцію від колективу, працюючи віддалено.

Чоловіки менше отримують зворотний зв'язок щодо виконаної віддалено роботи, ніж жінки. Працівники категорії «Б» та працівники 3 більшим стажем роботи також менше отримують зворотний зв'язок. Чим більший у працівника стаж роботи на займаній посаді, тим менше він вважає, що перебуває у постійному контакті 3 колегами структурного підрозділу та керівником 
8. Більшість державних службовців (64,1 \%) вважають, що у їхньому структурному підрозділі здійснюється систематичне планування роботи та контроль за виконавською дисципліною працівників, що працюють віддалено, а також вважають, що мають всі матеріали (56,2 \%) та технічне обладнання $(61,9$ \%) для виконання роботи віддалено.

Жінки більше, ніж чоловіки згодні з твердженнями, що у них ведеться планування та контроль за роботою у віддаленому режимі, а також, що вони отримують всю необхідну від служби управління інформацію щодо роботи віддалено.

Працівники категорії «Б» менше схильні вважати, ніж працівники категорії «В», що отримують достатній обсяг інформації від керівництва про те, що відбувається всередині державного органу, а також, що мають всі необхідні матеріали для виконання своєї роботи у віддаленому режимі.

9. Виявлено, що більше як половині державних службовців комфортно виконувати свої посадові обов'язки віддалено $(55,9$ \%) та їм вдається знаходити баланс між роботою у віддаленому режимі та особистим життям (54\%)

Працівники категорії «В», порівняно з працівниками категорії «Б», більше схильні зазначати про те, що після переходу на віддалений режим рівень їхньої мотивації підвищився, робота у віддаленому режимі стимулює їх розвиватися та навчатись, а також їм вдається знаходити баланс між роботою у віддаленому режимі та особистим життям.

Робота у віддаленому режимі найбільше стимулює розвиватися і навчатися працівників вікових категорій до 25 років та від 55 років, крім того працівникам зазначених вікових категорій краще вдається знаходити баланс між роботою та особистим життям.

Чим старший за віком працівник та чим більший у нього стаж, тим менш комфортно йому виконувати посадові обов'язки віддалено.

10. Встановлено вплив частоти застосування засобів телекомунікаційного зв' язку на оцінку респондентами особливостей комунікації, організаціїроботи та самоорганізацію. Тобтозбільшення частоти застосування різноманітних засобів телекомунікаційного 
зв'язку, таких як електронна пошта, месенджери, засобів відеозвязку, планування роботи, системи електронного документообігу суттєво підвищують позитивне сприйняття та оцінку державними службовцями віддаленої роботи, допомагають перебувати у контакті 3 колегами та оперативно реагувати на нові виклики.

11. Під час роботи у віддаленому режимі працівники стикаються 3 рядом труднощів, які ми згрупували за 8 напрямами:

- організація роботи у структурному підрозділі та/або державному органі - включає труднощі пов'язані з відсутністю єдиного механізму налагодження віддаленої роботи на державному рівні, організацією роботи у віддаленому режимі у структурному підрозділі, прийняттям рішень, недостатнім рівнем знань керівників та підпорядкованих працівників для забезпечення якісної та ефективної роботи у віддаленому режимі, відсутністю налагодженої оперативної взаємодії, понаднормовою роботою, демотивацією.

- $\quad$ внутрішня комунікація та зворотний зв'язок - дефіцит комунікації з керівництвом та колегами, нестача зворотного зв'язку від вищого керівництва, негативна оцінка міжособистісних відносин та командного духу в колективах.

- $\quad$ зовнішня комунікація - складнощі у встановленні оперативного та своєчасного зв'язку 3 працівниками інших державних органів і стейкхолдерами.

- самоорганізація та баланс між роботою та особистим життям - дисбаланс робочого часу та часу відпочинку, труднощі у самоорганізації, організації та розподілі часу на роботу та сім'ю.

- психологічні чинники - відчуття соціальної та інформаційної ізоляції, відсутність мотивації, складність концентруватися, стрес та напруга, переживання ізольованості, відсутності живого спілкування.

- технічні труднощі та доступи - відсутність налаштувань, доступів і збоїв у роботі на відстані, відсутність програмного забезпечення, низька якість інтернет -з'єднання, відсутність або проблеми з роботою у системі електронного документообігу тощо.

- необхідність перебування на робочому місці в межах адміністративної будівлі - зазначено обставини, за умови настання 
яких працівники, які працюють на відстані, зазнають труднощів оскільки потребують фізичного доступу до інших працівників, приміщень, документів, інформації (даних), які знаходяться в межах адміністративної будівлі державного органу.

- $\quad$ негативне ставлення до віддаленої роботи (опір змінам) складно працювати віддалено через негативне ставлення колег до роботи на відстані та їх небажання змінювати стиль роботи.

12. Більшість державних службовців (> 70 \%) вважають, що рівень ефективності, якості та виконавської дисципліни їхнього структурного підрозділу та державного органу з часу переходу на віддалений режим загалом не змінився.

При цьому працівники категорії «В» порівняно 3 працівниками категорії «Б» оцінюють ефективність роботи та виконавську дисципліну загалом вище та більше схильні вважати, що такі показники покращилися. Жінки оцінюють якість роботи та виконавську дисципліну свого структурного підрозділу 3 часу переходу на віддалену роботу вище, ніж чоловіки. Щодо порівняння за віком, то старші працівники більше схильні вважати, що ефективність роботи структурного підрозділу з часу переходу на віддалений режим погіршилася.

13. Застосування окремих засобів телекомунікаційного зв'язку підвищує ефективність, якість та виконавську дисципліну структурного підрозділу та державного органу.

Зокрема, ефективності роботи сприяє застосування Telegram, WhatsAp, Trello, Skype, Zoom,Google Docs, системи електронного документообігу, якості - Telegram, WhatsAp, Slack, Zoom, Meet, виконавській дисципліні - Viber, Trello.

Також, чим більше застосовано офіційні письмові роз'яснення, як форму роз'яснювальної роботи щодо організації роботи у віддаленому режимі, тим вище державні службовці оцінюють ефективність, якість та виконавську дисципліну у своєму державному органі.

14. Більша половина респондентів вважають, що на рівні їхнього структурного підрозділу (64,7 \%) та на рівні їхнього державного органу (50,8 \%) достатньо вжито заходів для організації роботи у 
віддаленому режимі. Водночас більшість $(56,4$ \%) вважають, що на рівні держави таких заходів вжито недостатньо.

15. Більшість опитаних державних службовців $(68,1 \%)$ надалі хотіли б поєднувати віддалену роботу з очною, 19,6 \% - не хотіли б працювати віддалено та 12,3 \% - хотіли б перейти на віддалений режим роботи.

Серед працівників, які працюють зараз віддалено 86,5 \% та тих, що працюють віддалено, а робоче місце відвідують відповідно до графіку чергувань, хотіли б і надалі працювати віддалено 92,8 \%. Серед тих, хто працює у штатному режимі - 66,4 \%.

Отже, практика віддаленої роботи може стати ефективним інструментом, де в плюсі будуть, як державні службовці так і державна служба зокрема. Для цього потрібно знайти правильний підхід до організації віддаленої роботи та врегулювати це питання на законодавчому рівні.

Наразі HR зазнає серйозних і глибинних змін. HR тренди зададуть нові підходи до підвищення ефективності: перехід на віртуальні робочі місця і гнучка зайнятість, використання i розвиток digital простору, автоматизація i цифровізація у всіх сферах управління персоналом, розвиток організаційних соціальних мереж, онлайн навчання у будь-якому місці та у будь-який час, персональний підхід тощо. Все це формуватиме подальші уявлення про розвиток сфери управління персоналом на державній службі.

У сучасних умовах гнучкі форми зайнятості підвищать спроможністьдержавнихорганівта якість життя державнихслужбовців, а технології спільної роботи допоможуть успішно втілювати їх у життя. Однак практика віддаленої роботи може стати ефективним інструментом лише в тому випадку, якщо вона буде поширюватися на весь державний орган, а не на категорію «обраних осіб». На жаль, багато керівників виявилися не готовими до керівництва на віддалі.

Водночас варто пам'ятати, що віддалена робота без належної підготовки (зокрема, навчання, методичного супроводу) та підтримки з боку керівництва, колег і сім’ї негативно впливає на продуктивність працівників. 
Відтак цьогорічний кейс з карантином підштовхує нас до вирішення проблем, про які ми завжди знали, але вважали за краще ігнорувати. Дистанційна (віддалена) робота в тій чи іншій мірі була завжди, проте через появу COVID-19 значно прискорилось iii визнання та 3'явилася необхідність у забезпеченні організації переходу на віддалену роботу у державних органах задля збереження сталості та якості їх функціонування в умовах карантину.

Висновки. Враховуючи зазначене вище можемо рекомендувати, що для організації ефективної та якісної роботи у віддаленому режимі в органах державної влади необхідно здійснити наступне.

\section{На рівні держави:}

1. Розробити централізований підхід до організації віддаленої роботи та врегулювати це питання на законодавчому рівні.

2. Забезпечити формування підзаконних рамок і стандартів організації роботи у віддаленому режимі на державній службі (наприклад, нормативно-правове регулювання, затвердження єдиних стандартів і процедур, централізоване методологічне забезпечення і навчання).

3. Провести автоматизацію і цифровізацію у сфері управління персоналом.

4. Покращити / забезпечити впровадження електронного документообігу в державних органах усіх рівнів.

5. Розробити та впровадити робочий механізм (методологічна, нормативна та/або законодавча рамка, а також IT інструменти) для налагодження комунікації у віддаленому режимі між державними органами та іншими заінтересованими особами, громадськістю шляхом здійснення переадресації дзвінків, повідомлень, листів, інших документів тощо.

6. Посилити інформаційну роз'яснювальну роботу серед державних органів щодо запроваджених на рівні державних заходів стосовно організації роботи у віддаленому режимі.

\section{На рівні державних органів:}

1. Прийняти в межах компетенції локальні нормативні рішення державного органу щодо організації роботи у віддаленому режимі.

2. Надати методичну допомогу щодо організації віддаленої 
роботи зі сторони центральних органів виконавчої влади щодо підпорядкованих установ та організацій.

3. Передбачити матеріальні ресурси для переходу на віддалені робочі місця.

4. Створити умови для використання і розвитку digital простору та технологій спільної роботи, розвитку організаційних соціальних мереж.

5. Забезпечити навчання керівників щодо організації роботи та керівництва на відстані.

6. Організувати навчання державних службовців щодо застосування у роботі сучасних засобів телекомунікаційного зв' язку.

7. Врегулювати питання створення доступної бази контактів (телефонів, електронних пошт), які не є персональними даними (наприклад, через переадресацію чи контакт центр) та розмістити іiі на офіційному веб-сайті державного органу.

8. Налагодити оперативну комунікацію всередині державного органу шляхом застосування сучасних засобів телекомунікаційного зв'язку.

9. Запровадити щотижневі онлайн-наради 3 керівниками структурних підрозділів.

10. Проводити службами управління персоналом державних органів роз'яснювальну роботу серед працівників щодо організації віддаленої роботи.

11. Забезпечити технічну підтримку працівників при переході на віддалену роботу (доступи до необхідних програм, за можливості видача робочих ноутбуків,встановлення системи електронного документообігу на особистий комп’ютер, налаштування доступу до робочої електронної пошти тощо).

12. Розширити спектр застосування засобів телекомунікаційного зв’язку для комунікації та взаємодії всередині державного органу.

13. Налагодити механізм оперативного опрацювання та погодження проектів документів у керівництва та співвиконавців в електронному вигляді.

14. Визначити критичні функції, виконання яких потребує обов'язкового перебування працівника у межах адміністративної 
будівлі постійно або відповідно до графіку чергувань.

15. Забезпечити з боку керівників державних органів підтримку переходу на віддалену роботу їх працівників.

\section{На рівні структурних підрозділів:}

1. Забезпечити керівниками структурних підрозділів організацію, планування та контроль роботи у віддаленому режимі (зокрема, проводити онлайн-наради, здійснювати щоденну постановку завдань онлайн, розробити механізм контролю тощо).

2. Забезпечити надання керівниками методичної підтримки підпорядкованим працівникам щодо роботи у віддаленому режимі.

3. Здійснити рівномірний розподіл навантаження на працівників, які працюють у віддаленому режимі.

4. Оперативно надавати та отримувати зворотний зв’язок щодо виконаної роботи.

5. Застосовувати сучасні засоби телекомунікаційного зв'язку, зокрема, щодо дистанційної організації роботи (наприклад, Trello, Slack), організації онлайн-нарад (наприклад, Skype, Zoom, Meet, Cisco Webex), оперативної комунікації (наприклад, Viber, Trello, WhatsApp).

6. Запровадити спільну роботу над документами онлайн шляхом застосування, наприклад, GoogleDocs.

7. Окреслити рамки робочого часу та визначити правила електронної комунікації.

\section{На рівні окремих працівників:}

1. Розвивати особисту відповідальність за свій внесок у загальних результат роботи структурного підрозділу / державного органу.

2. Здійснити організацію робочого місця вдома.

3. Бути на зв'язку у робочий час, підтримувати та ініціювати комунікацію з колегами.

4. Планувати свій робочий час та час відпочинку.

5. Займатися самоосвітою, зокрема розвивати власну цифрову грамотність.

Стаття надійшла до редакції: 05.01.21 


\section{REMOTE WORK IS A NEW MODEL OF THE ORGANIZATIONAL AND INSTITUTIONAL DEVELOPMENT OF THE CIVIL SERVICE IN UKRAINE}

Nataliia Aliushyna, PhD in Psychology, Head of the National Agency of Ukraine on Civil Service, Kiev, 01601, Ukraine.

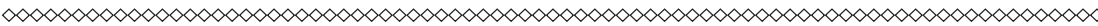

The results of a study of the practice of organizing remote work in the civil service of Ukraine during the quarantine caused by COVID-19 are revealed. The description of ways and features of the organization of remote work is carried out. The differences in the ways of organizing remote work in government agencies of different levels of jurisdiction are highlighted. A detailed and systematic analysis of the causes and factors that may have a direct and indirect impact on the process of transition to remote work format. The role of various factors which in the general analysis give the chance to come to a conclusion that these factors are system-dependent from each other, and in separate cases complement each other is shown. A study was conducted by civil servants to assess the level of their efficiency, quality and executive discipline since the transition to remote work. A comparison of relationships with the features of remote work by job category, age, experience and gender. Problems that need to be solved within the framework of remote operation implementation have been identified. Five main trends in the organization of remote work are identified: stimulation of learning and self-development; promotion of IT tools in the civil service; awareness of the importance of communication and interaction; development of tools for intangible team incentives; adaptability of workers to new working conditions, moderate resistance to change.

Keywords: remote work, civil service, civil servants, organization of remote work, COVID-19, personnel management.

Received: 05.01.21 


\section{References}

1. Nakaz NADS Pro vnesennia zmin do Typovykh pravyl vnutrishnoho sluzhbovoho rozporiadku: vid 13 bereznia 2020 roku No 39-20, zareiestrovanyi v Ministerstvi yustytsii Ukrainy 16 bereznia 2020 roku za No 277/34560 [NAPS Order on Amendments to the Standard Rules of Internal Procedure: dated March 13, 2020 No 39-20, registered with the Ministry of Justice of Ukraine on March 16, 2020 for No 277/34560]. zakon.rada.gov.ua. Retrieved from https://zakon. rada.gov.ua/laws/show/z0277-20 [in Ukrainian].

2. Ahuja, S. \& Kaur, P. \& Panda, S.N. (2019). Identification of Influencing Factors for Enhancing Online Learning Usage Model: Evidence from an Indian University. International Journal of Education and Management Engineering (IJEME), (Vol. 9), 2, (pp. 15-24) [in English].

3. Bondarenko, O.M. \& Rishko, Yu.I. \& Tardaskina, T.M. (2018). Perevahy viddalenoi roboty yak efektyvnoi formy zainiatosti personalu $\mathrm{v}$ suchasnykh umovakh [Advantages of remote work as an effective form of staff employment in modern conditions]. $B Y-B I, 12$ (491), (pp. 425-430) [in Ukrainian].

4. Kryvosheieva, V.\& Vasiurenko, L. (2020). Motyvuiucha komponenta za dystantsiinoi formy zainiatosti personal [Motivating component in the remote form of employment]. Ekonomika ta pravlinnia AP - Economics and Management AP, 1, (pp. 93-100) [in Ukrainian].

5. Hassan, M.M. \& Mirza, T. \& Hussain, M.W. (2020). A Critical Review by Teachers on the Online Teaching-Learning during the COVID-19. International Journal of Education and Management Engineering (IJEME), (Vol. 10), 5, 2, (pp. 17-27) [in English].

6. Hassan, M.M. \& Mirza, T. \& Hussain, M.W. (2020). Impact of COVID-19 Pandemic on the Human Behavior. International Journal of Education and Management Engineering (IJEME), (Vol. 10), 5, (pp.35-61) [in English].

7. Shafiee, N.S.M. \& Mutalib, S. (2020). Prediction of Mental Health Problems among Higher Education Student Using Machine Learning. International Journal of Education and Management Engineering (IJEME), (Vol. 10), 6, (pp. 1-9) [in English].

8. Nevmerzhytska, S. (2020). Perevahy ta problemy dystantsiinoi formy zainiatosti personalu, Aktualni problemy ekonomiky, obliku, finansiv $i$ 
prava: zbirnyk tez dopovidei mizhnarodnoi naukovo-praktychnoi konferentsii [Advantages and problems of the remote form of employment of the personnel, Actual problems of economy, the account, finances and the right: the collection of theses of reports of the international scientific and practical conference]. Poltava, Ch., 10, (pp. 32-35) [in Ukrainian].

9. Shchetinina, L. \& Pavlova, K. \& Rudakova, S. (2015). Osoblyvosti rozvytku korporatyvnoi kultury $\mathrm{v}$ umovakh viddalenoho rezhymu roboty [Peculiarities of corporate culture development in the conditions of remote work mode]. Problemy ekonomiky - Problems of economy, 3, (pp. 175-180) [in Ukrainian].

10. Rudenok, A. \& Petiak, O. \& Khanetska, N. (2020). Dystantsiina robota $\mathrm{v}$ umovakh karantynu ta samoizoliatsii v period pandemii COVID-19 [Remote work in the conditions of quarantine and self-isolation during the pandemic COVID-19]. Psykholohiia pratsi - Psychology of work, 16, (pp. 204-208) [in Ukrainian].

11. Civil Service Employee Engagement Survey. COVID-19 Remote Working Report: Government of Ireland. (2020). www.gov.ie. Retrieved from https://www.gov.ie [in English].

12. O'Kane, P. \& Walton, S. \& Ruwhiu, D. (2020). Remote Working during COVID19. New Zealand National Survey: Initial Report. hotago.ac.nz. Retrieved from https://otago.ac.nz [in English].

\section{Відомості про авторів / Information about the Authors}

Алюшина Наталія Олександрівна: Національне агентство України 3 питань державної служби: вул. Прорізна, 15, м. Київ, 01601, Україна.

Nataliia Aliushyna: National Agency of Ukraine on Civil Service: 15 Prorizna str., Kiev, 01601, Ukraine.

ORCID. ORG./ 0000-0003-1333-3800

\section{E-mail: natalyushina@gmail.com}

